\title{
Project Cost Escalation Prediction Models Based on System Dynamics Approach
}

\author{
Y. Suponco Wisnu Broto ${ }^{1 *}$, Tri Joko Wahyu Adi ${ }^{1,2}$, Erma Suryani ${ }^{1,3}$, Jojok Widodo Soetjipto ${ }^{4}$ \\ ${ }^{I}$ Master Management of Technology Institut Teknologi Sepuluh Nopember \\ ${ }^{2}$ Department of Civil Engineering Institut Teknologi Sepuluh Nopember \\ ${ }^{3}$ Department of Informatics Engineering Institut Teknologi Sepuluh Nopember \\ ${ }^{4}$ Department of Civil Engineering University of Jember \\ *Corresponding author: (wisnubroto.ponco@gmail.com)
}

\begin{abstract}
Multiyear construction project is one of the riskiest project due to uncertainty and dynamic economic condition. In multi-years project, cost escalation is inevitable because during construction period various risk factors such as increasing of labor cost, materials cost, energy cost, and equipment cost will affect the costs of the projects. This paper proposes a model to estimate cost escalation based on System Dynamic (SD) approach. SD is used to represent correlation among risk factors influencing cost escalation and to calculate cost escalation during project period. Causal Loop Diagram (CLD) was made based on in-depth literature review and confirmed by the experts. To validate the model, 7 multi-years projects in Indonesia were used as case study. The result showed that the proposed model can accurately predict project cost escalation with an accuracy of $91.21 \%$. Simulation of SD also showed that the change of scope of work, ambiguous contract condition, unpredictable conditions, project schedule delay, inflation, and extreme weather condition are the most influencing factor of cost escalation. Besides predicting cost escalation of project, this model can also be used as early warning system in multi-year projects environment.
\end{abstract}

Keywords—Cost escalation, Risk, Multi years Construction Project, System Dynamic.

\section{INTRODUCTION ${ }^{1}$}

$\mathrm{T}_{\mathrm{b}}$ he implementation period of the construction project is single year and multi years. Single year construction project is a project activity whose implementation period is less than or equal to one year (twelve months). Meanwhile, multi-years construction project is a project with the period of more than one year. Multi-years projects certainly have a lot of risk in the implementation process. One of the risks in multi-years projects is price adjustment or commonly called as cost escalation. Cost escalation is the adjustment of unit price of contract component which includes labor, construction materials, energy and equipment to contract value during bid (Cornell, 2010 in Banjarmasin Municipal Government, 2010).

The cost of completing the construction is made up of the volume of work based on the drawing and job specification and the unit price of the work obtained from the unit price analysis. In practice, the unit price of the work must be accordance with the specifications set in both drawing and requirement and considering the technical conditions of the field at the project site to obtain accurate estimation result. The cost of a construction project is definitely also influenced by its implementation period, especially multi-years projects.

The intensity of construction project activities change throughout the project. This is certainly become a particular concern for multi-years projects. Multi-years project with duration of more than one year will potentially have risks in the execution period, not only from economic fluctuations that affect cost escalation but also from some other things like bad weather, changes in the scope of work, job delays, labour strike, and technical issues (image, specification, and contract changes). The situation as mentioned above will greatly affect the implementation period and project cost if it is not anticipated, especially on the problem of economic fluctuations that affect cost escalation.

The cost of the project is influenced by many factors and the factors are related to each other/dependent. Project cost will also change over time, which means the likelihood of changing costs is affected by the passage of time. As time goes by, these factors change as well, as a result the cost also changes. Michael Kareth et.al. (2012) explains that project costs will increase if project implementation time is being slowed/extended. To approach the characteristic condition as above, it can be approached by a dynamic system model approach. Model with dynamic system approach can provide insight into the interdependencies and behaviours among key variables that contribute to cost escalation, so that it can be used in the learning and improvement process for other multi-years projects in the future more efficiently.

Previously, there have been many literatures/research conducted on cost escalation in construction projects, some of them are Kumalasari, I. and Hapsari, M. (2005) conducting escalation calculation research using leading economic indicators as an alternative to escalation calculation; Touran, A. and Lopez, R. (2006) describing a computer model designed to combine the effects of 


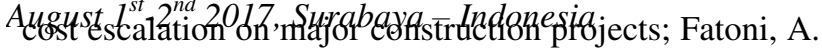
and Hanif, M. (2013) reviewing cost escalation in multiyears infrastructure projects with case studies of the Jatigede Reservoir Construction Project and Jatibarang Reservoir Construction Project with the procedure of calculation in accordance with Presidential Decree Number 70 Year 2012 article 92 paragraph 3; and Vamsidhar, K. et al (2014) which discussed the rapid increase in the prices of construction materials, labour, and equipment costs to determine the percentage increase in construction costs.

Every method used in the above research has weaknesses and advantages. The fundamental weakness of the method is that they did not describe the relationship between factors/variables that can lead to cost escalation. From the above research, dynamic system was still not used as research method. Whereas in reality, many factors affect the escalation of project costs. These factors are also correlated between one and another. In the implementation of a long time project, as in a multi-years project, the condition changes over time. The dynamic system is a method that can accommodate and eliminate the disadvantages of previous escalation estimation methods. Therefore, this research will use dynamic system as research method to find the relationship/interaction between factors that influence the cost escalation and to find out the amount of cost escalation in multi-years projects. The purpose of this research is to identify the factors which cause cost escalation, to form a model of relationship between factors which cause cost escalation, and to study trend or the tendency of cost escalation in multi-years projects.

\section{METHOD}

This research used dynamic system modeling to be able to see the effect of each variable on the real system which the purpose is to find something in the amount of escalation cost and to study its tendency in multi years project. This research tries to capture the phenomenon of uncertainty in the implementation of construction project caused by the duration factor of project implementation which is more than one year. This uncertainty is a risk to the implementation of a construction project that has a cost impact to the contractor as the project implementer. By knowing the amount of escalation cost, the contractor can take some actions to reduce the potential risk.

\section{A. Definition of Operational Variable}

Definition of operational variable used to facilitate the collection of data, both secondary data and primary data on the object of this study which will be shown in Table 1.

Table 1. Variables and Operational Definition of Variables That Cause Cost Escalation

\begin{tabular}{|c|c|c|c|c|}
\hline No. & Variable & Indicator & Operational Definition & Sources \\
\hline 1. & Bad weather & $\begin{array}{l}\text { Rainfall } \\
\text { intensity }\end{array}$ & $\begin{array}{l}\text { The amount of rain falling is expressed in rainfall } \\
\text { intensity volume per unit time. }\end{array}$ & $\begin{array}{l}\text { Peter Morris dan William } \\
\text { F. Willson (2006) dan } \\
\text { Chabota Kaliba, Mundia } \\
\text { Muya, dan Kanyuka } \\
\text { Mumba (2008) }\end{array}$ \\
\hline \multirow[t]{2}{*}{2.} & \multirow[t]{2}{*}{ Inflation rate } & $\begin{array}{l}\text { Material price } \\
\text { fluctuation }\end{array}$ & $\begin{array}{l}\text { Changes in the inflation or deflation of material } \\
\text { prices that occurred during the multi-years project } \\
\text { implementation period. }\end{array}$ & \multirow{2}{*}{$\begin{array}{l}\text { Chabota Kaliba, Mundia } \\
\text { Muya, dan Kanyuka } \\
\text { Mumba (2008); S. Shane, } \\
\text { A., Keith R. Molenaar, } \\
\text { Stuart Anderson, dan } \\
\text { Cliff Schexnayder } \\
\text { (2009); dan Ali Touran } \\
\text { dan Ramon Lopez (2006) }\end{array}$} \\
\hline & & $\begin{array}{l}\text { Fluctuation of } \\
\text { equipment } \\
\text { rental price }\end{array}$ & $\begin{array}{l}\text { Changes in the inflation or deflation of equipment } \\
\text { rental prices that occurred during the multi-years } \\
\text { project implementation period. }\end{array}$ & \\
\hline 3. & $\begin{array}{l}\text { Unexpected } \\
\text { condition }\end{array}$ & $\begin{array}{l}\text { Condition of } \\
\text { existing land }\end{array}$ & $\begin{array}{l}\text { Differences in expected conditions during the } \\
\text { design/planning stage with the conditions under } \\
\text { construction. }\end{array}$ & $\begin{array}{l}\text { S. Shane, A., Keith R. } \\
\text { Molenaar, Stuart } \\
\text { Anderson, dan Cliff } \\
\text { Schexnayder (2009) }\end{array}$ \\
\hline \multirow[t]{3}{*}{4.} & \multirow[t]{3}{*}{$\begin{array}{l}\text { Changes/additions } \\
\text { to the scope of } \\
\text { work }\end{array}$} & $\begin{array}{l}\text { Design } \\
\text { changes }\end{array}$ & $\begin{array}{l}\text { At the design stage there is an activity that has not } \\
\text { been covered in the design plan. }\end{array}$ & \multirow{3}{*}{$\begin{array}{l}\text { Chabota Kaliba, Mundia } \\
\text { Muya, dan Kanyuka } \\
\text { Mumba (2008); S. Shane, } \\
\text { A., Keith R. Molenaar, } \\
\text { Stuart Anderson, dan } \\
\text { Cliff Schexnayder } \\
\text { (2009); Towhid } \\
\text { Pourrostam, Amiruddin } \\
\text { Ismail, dan Mahmood } \\
\text { Mansournejad (2011); } \\
\text { dan Ade Nurmala dan } \\
\text { Sarwono Hardjomuljadi } \\
\text { (2015) }\end{array}$} \\
\hline & & $\begin{array}{l}\text { Material } \\
\text { specification } \\
\text { changes }\end{array}$ & $\begin{array}{l}\text { At the design stage there is a material } \\
\text { specification that is no longer produced in the } \\
\text { market and the project owner's desire to change } \\
\text { the material specification. }\end{array}$ & \\
\hline & & $\begin{array}{l}\text { Acceleration } \\
\text { of work }\end{array}$ & $\begin{array}{l}\text { The need to increase the number and hours of } \\
\text { labor in the process of completion of the project. }\end{array}$ & \\
\hline
\end{tabular}




\begin{tabular}{|c|c|c|c|c|}
\hline No. & Variable & Indicator & Operational Definition & Sources \\
\hline \multirow[t]{5}{*}{5.} & $\begin{array}{l}\text { Project } \\
\text { schedule } \\
\text { delay }\end{array}$ & Design changes & $\begin{array}{l}\text { At the design stage there is an activity that has not } \\
\text { been covered in the design plan. }\end{array}$ & $\begin{array}{l}\text { Sadi A. Assaf dan Sadiq Al- } \\
\text { Hejji (2006); dan M. E. Abd }\end{array}$ \\
\hline & & $\begin{array}{l}\text { Late payment } \\
\text { progress from } \\
\text { owner }\end{array}$ & $\begin{array}{l}\text { The number of days of late payment that is not in } \\
\text { accordance with the agreement in the contract. }\end{array}$ & $\begin{array}{l}\text { El-Razek, H. A. Bassioni, } \\
\text { and A. M. Mobarak (2008) }\end{array}$ \\
\hline & & $\begin{array}{l}\text { Ineffective } \\
\text { planning from } \\
\text { contractors }\end{array}$ & $\begin{array}{l}\text { How much does contractor understand in preparing } \\
\text { project scheduling especially in terms of continuity } \\
\text { of work. }\end{array}$ & $\begin{array}{l}\text { Sadi A. Assaf dan Sadiq Al- } \\
\text { Hejji (2006) }\end{array}$ \\
\hline & & $\begin{array}{l}\text { Shortage of } \\
\text { labor }\end{array}$ & $\begin{array}{l}\text { Availability of existing workforce at a construction } \\
\text { site location resulting from late payment of } \\
\text { progress from the owner }\end{array}$ & $\begin{array}{l}\text { Sadi A. Assaf dan Sadiq Al- } \\
\text { Hejji (2006) }\end{array}$ \\
\hline & & Bad weather & $\begin{array}{l}\text { The amount of rain falling is expressed in rainfall } \\
\text { or rainfall volume per unit time. }\end{array}$ & $\begin{array}{l}\text { Peter Morris dan William F. } \\
\text { Willson (2006); Chabota } \\
\text { Kaliba, Mundia Muya, dan } \\
\text { Kanyuka Mumba (2008); } \\
\text { Sadi A. Assaf dan Sadiq Al- } \\
\text { Hejji (2006); dan Perez, P. } \\
\text { B., et al (2015) }\end{array}$ \\
\hline 6. & $\begin{array}{l}\text { The } \\
\text { ambiguous } \\
\text { terms of the } \\
\text { contract }\end{array}$ & $\begin{array}{l}\text { Understanding } \\
\text { the contents of } \\
\text { contract } \\
\text { documents }\end{array}$ & $\begin{array}{l}\text { How much the contractor understands the contents } \\
\text { of contract documents, especially in terms of } \\
\text { material specifications and implementation } \\
\text { methods. }\end{array}$ & $\begin{array}{l}\text { S. Shane, A., Keith R. } \\
\text { Molenaar, Stuart Anderson, } \\
\text { dan Cliff Schexnayder } \\
\text { (2009) dan Ali Touran dan } \\
\text { Ramon Lopez (2006) }\end{array}$ \\
\hline 7. & $\begin{array}{l}\text { Local area } \\
\text { requirements }\end{array}$ & Social culture & $\begin{array}{l}\text { Noise level, environmental hygiene, norms } \\
\text { prevailing in the community, trust. }\end{array}$ & $\begin{array}{l}\text { S. Shane, A., Keith R. } \\
\text { Molenaar, Stuart Anderson, } \\
\text { dan Cliff Schexnayder } \\
(2009)\end{array}$ \\
\hline
\end{tabular}

\section{B. Secondary Data}

The secondary data used in this study includes what events that have been experienced in multi-years projects related to the factors from the literature study.

1. Material price fluctuation and rental tools related to the inflation rate variable occurring in construction projects every year. The data taken is the list price of materials and rental tools used by contractors that have been agreed with the suppliers.

2. Data changes/addition of the scope of work that occurs, taken from the list of total changes of work that has been quantified in value compared with the initial contract value.

3. The ambiguous contract terms data that are derived from the list of work items arising from the ambiguous contract terms and already quantified in value compared to the first original contract value.

4. The unexpected conditions data that occurs, derived from the list of budget expenses incurred during the construction period for unexpected things.

5. Data on the delay of the project schedule that occurred, is obtained from the comparison between the difference between the number of initial contract work days and the change data (addendum contract).

6. The intensity of rainfall associated with the bad weather variable that has occurred at the project site. The data taken is the weather monitoring made by the contractor every day during the project implementation period.

7. The availability of the amount of material and labor that available at a construction site location related to high volume variable of construction work, especially in the middle of the year until the end of the year. The data taken is the contractor's daily report data in the middle of the year to the end of the year.

8. The local area requirements data obtained from the list of expenditures caused by the requirements of the environment around the project. In addition, this data also includes the amount of loss of job performance because of the requirements area around the project.

\section{Primary Data}

Primary data in this research is obtained by doing direct observation and interview. The interview is conducted with competent sources/expert in terms of multi-years projects. Expert criteria in this case are those who served project managers in a project over 10 years, experienced in multi-years projects, and have project manager reputation in undertaking multi-years projects that never suffered losses. The primary data collection taken for this study through the experts/expert based on the operational definition of the variable, consisting of:

1. Identity data of the respondent/project.

2. Data variable causes of cost escalation that has been validated. 
3. The probability data influence the change of material specification, acceleration of work, design changes, payment of progress delay from the owner, ineffective planning by contractor, and labor shortage to changes/addition of scope of work and delay of project schedule.

4. Data form of the interaction/relationship of each variable on the system.

\section{Design of Causal Loop Diagram}

At this stage, it will be described various relationships between variables forming. In determining and understanding the relationship form of each variable, it conducted interview to the project manager. The Causal Loop Diagram of this research is formed from the results of several literature studies and verified by the project manager. Each of the corresponding variables will be connected by an arrow. The tail of the arrow indicates causation while the head of the arrow shows the effect of a cause. The causal loop diagram of this research can be seen in Figure 1.

\section{E. Modeling Scenario}

At this stage, it will be done two scenario modeling, there are parameter scenario and structure scenario. The parameter scenario is done by changing the parameter values of the model and then seeing the impact on the model output, meanwhile the structure scenario is done by changing the model structure. The structural scenario is done to include additional factors that can minimize the cost of multi-years projects cost escalation into the initial model. The factors included in the model are

\section{RESULTS AND DISCUSSION}

\section{A. Data Processing}

Research data that is collected and then processed to get equation formula influence between factors according to Figure 1. Equation of this formula which later will be used for the manufacture of dynamic system model with Vensim software. Formulation is derived from the application of statistical data processing techniques namely Multiple Linear Regression with Principal Component Analysis (PCA) approach. The PCA approach needs to be implemented because of the larger number of predictor variables than the dependent variable. PCA has the ability to reduce many predictor variables to a few new variables but still have a correlation. This new predictor variable is used for the analysis of Multiple Linear Regression. The data processing is done with Minitab Software 16.

In the application of data processing influence between these factors, there are two types of variables used; predictor variables and dependent variables. Predictor variables are factors that have an effect of change on other factors according to Figure 1. Otherwise, the dependent variable is a factor influenced by other factors. These predictor variables and dependent variables are then searched for the relation into equation. Equations are made on each dependent variable that is influenced by one or more of its predictor variables. The following recapitulation equation of the formula of influence between factors obtained through multiple linear regression data processing is presented in Table 2 .

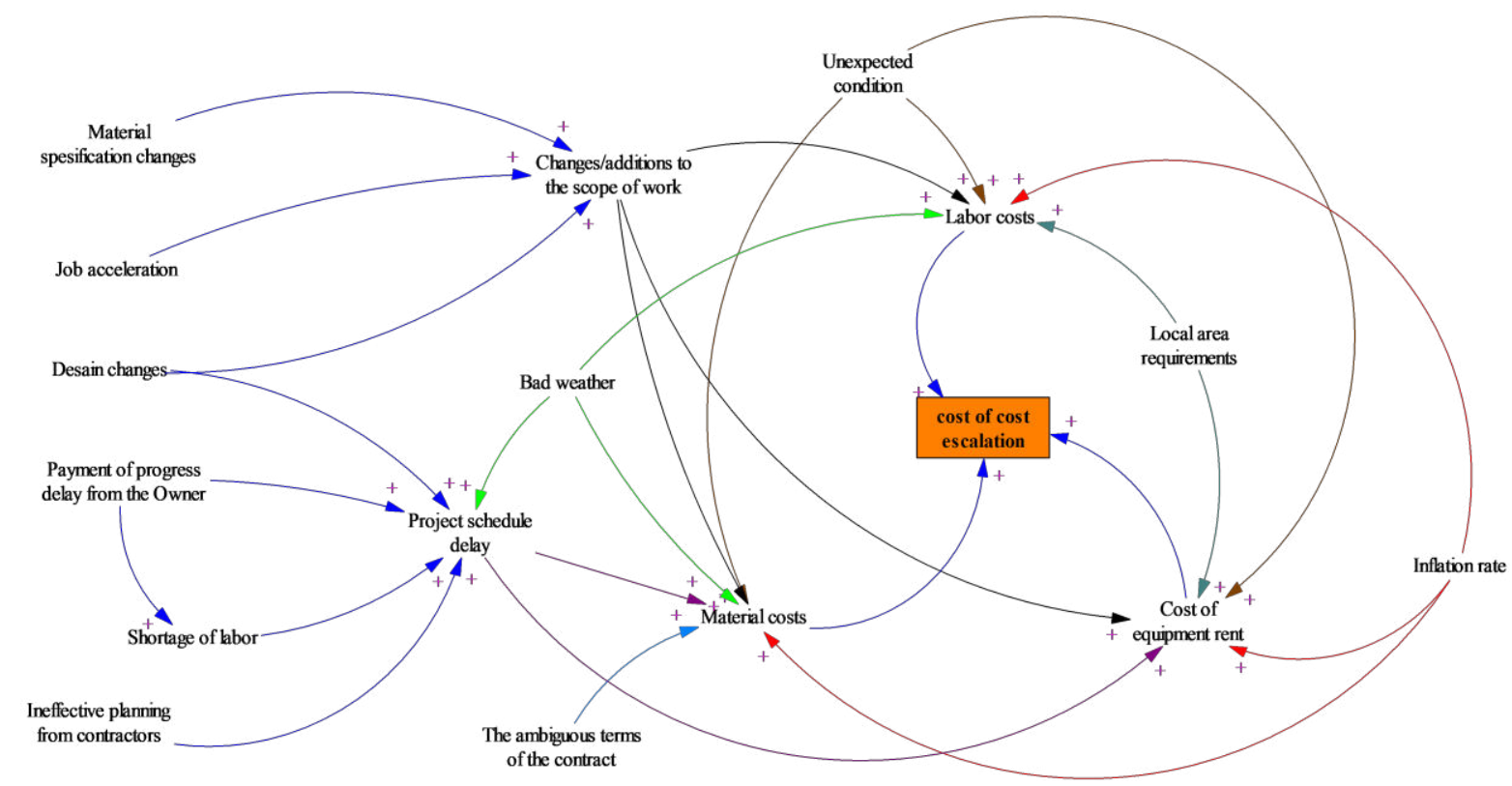

Figure 1. Causal Loop Diagram

detailed project schedule, risk mitigation, initial contractor engagement in design development, and experts involvement in the project. 


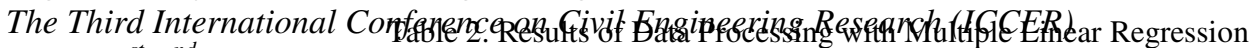
August $1^{\text {st }}-2^{\text {nd }}$ 2017, Surabaya - Indonesia

\begin{tabular}{|c|c|c|c|}
\hline No. & Related variable & Predictor variable & Multiple Linear Regression Equation \\
\hline 1. & $\mathrm{Y}:$ cost escalation & $\begin{array}{l}\mathrm{A}_{1}: \text { Material price } \\
\overline{\mathrm{A}_{1}}: \text { Average value } \\
\text { of material price } \\
\text { data } \\
\mathrm{SA}_{1}: \text { Standard } \\
\text { deviation of } \\
\text { material price data } \\
\mathrm{A}_{2}: \text { The price of } \\
\text { labor wages } \\
\overline{\mathrm{A}_{2}}: \text { Average value } \\
\text { of labor wage price } \\
\text { data } \\
\mathrm{SA}_{2}: \text { Standard } \\
\text { deviation of labor } \\
\text { cost price data } \\
\mathrm{A}_{3}: \text { Equipment } \\
\text { rental price } \\
\overline{\mathrm{A}_{3}}: \text { Average value } \\
\text { of euipment rental } \\
\text { price data } \\
\mathrm{SA}: \text { Standard } \\
\text { deviation of } \\
\text { equipment rental } \\
\text { price data }\end{array}$ & $\begin{array}{l}\mathrm{Y}= \\
0.0457+0.0106\left(0.682\left(\frac{A 1-\overline{A 1}}{S A 1}\right)-0.671\left(\frac{A 2-\overline{A 2}}{S A 2}\right)+0.290\left(\frac{A 3-\overline{A 3}}{S A 3}\right)\right)- \\
0.0190\left(0.161\left(\frac{A 1-\overline{A 1}}{S A 1}\right)-0.250\left(\frac{A 2-\overline{A 2}}{S A 2}\right)-0.955\left(\frac{A 3-\overline{A 3}}{S A 3}\right)\right)\end{array}$ \\
\hline 2. & $\mathrm{~A}_{1}$ : Material Price & $\begin{array}{l}\mathrm{X}_{1}: \\
\text { Changes/additions } \\
\text { to the scope of work } \\
\mathrm{X}_{2}: \text { Ambiguous } \\
\text { contract provisions } \\
\mathrm{X}_{3}: \text { Unexpected } \\
\text { conditions } \\
\mathrm{X}_{4}: \text { Project } \\
\text { schedule delay } \\
\mathrm{X}_{5}: \text { Inflation rate } \\
\mathrm{X}_{6}: \text { Bad weather } \\
\mathrm{X}_{1}-\overline{\mathrm{X}_{6}} \text { :Average } \\
\text { value data } \\
\mathrm{SX}_{1}-\mathrm{SX}_{6}: \\
\text { Standard deviation } \\
\text { data }\end{array}$ & $\begin{array}{l}A 1= \\
0.0670-0.003\left(0.462\left(\frac{X 1-\overline{X 1}}{S X 1}\right)+0.429\left(\frac{X 2-\overline{X 2}}{S X 2}\right)+0.445\left(\frac{X 3-\overline{X 3}}{S X 3}\right)+\right. \\
\left.0.430\left(\frac{X 4-\overline{X 4}}{S X 4}\right)+0.426\left(\frac{X 5-\overline{X 5}}{S X 5}\right)+0.196\left(\frac{X 6-\overline{X 6}}{S X 6}\right)\right)+ \\
0.0032\left(0.189\left(\frac{X 1-\overline{X 1}}{S X 1}\right)-0.362\left(\frac{X 2-\overline{X 2}}{S X 2}\right)-0.311\left(\frac{X 3-\overline{X 3}}{S X 3}\right)-\right. \\
\left.0.310\left(\frac{X 4-\overline{X 4}}{S X 4}\right)+0.511\left(\frac{X 5-\overline{X 5}}{S X 5}\right)+0.616\left(\frac{X 6-\overline{X 6}}{S X 6}\right)\right)- \\
0.0240\left(0.386\left(\frac{X 1-\overline{X 1}}{S X 1}\right)-0.413\left(\frac{X 2-\overline{X 2}}{S X 2}\right)-0.403\left(\frac{X 3-\overline{X 3}}{S X 3}\right)+\right. \\
\left.0.436\left(\frac{X 4-\overline{X 4}}{S X 4}\right)+0.221\left(\frac{X 5-\overline{X 5}}{S X 5}\right)-0.528\left(\frac{X 6-\overline{X 6}}{S X 6}\right)\right)\end{array}$ \\
\hline 3. & $\begin{array}{c}\mathrm{A}_{2}: \text { Price of labor } \\
\text { wages }\end{array}$ & $\begin{array}{l}\mathrm{X}_{1}: \\
\text { Changes/additions } \\
\text { to the scope of work } \\
\mathrm{X}_{3}: \text { Unexpected } \\
\text { condition } \\
\mathrm{X}_{5}: \text { Inflation rate } \\
\mathrm{X}_{6}: \text { Bad weather } \\
\mathrm{X}_{7}: \text { Local area } \\
\text { requirements } \\
\overline{\mathrm{X}}_{1}-\overline{\mathrm{X}_{7}}: \text { Average } \\
\text { value data } \\
\mathrm{SX}_{1}-\mathrm{SX}_{7} \text { : } \\
\text { Standard deviation } \\
\text { data }\end{array}$ & $\begin{array}{l}A 2=0.0729-0.00063\left(0.545\left(\frac{X 1-\overline{X 1}}{S X 1}\right)+0.235\left(\frac{X 3-\overline{X 3}}{S X 3}\right)+\right. \\
\left.0.558\left(\frac{X 5-\overline{X 5}}{S X 5}\right)+0.284\left(\frac{X 6-\overline{X 6}}{S X 6}\right)+0.506\left(\frac{X 7-\overline{X 7}}{S X 7}\right)\right)+ \\
0.00713\left(0.254\left(\frac{X 1-\overline{X 1}}{S X 1}\right)-0.582\left(\frac{X 3-\overline{X 3}}{S X 3}\right)-0.066\left(\frac{X 5-\overline{X 5}}{S X 5}\right)-\right. \\
\left.0.639\left(\frac{X 6-\overline{X 6}}{S X 6}\right)+0.428\left(\frac{X 7-\overline{X 7}}{S X 7}\right)\right)\end{array}$ \\
\hline
\end{tabular}


The Third International Conference on Civil Engineering Research (ICCER)

August $1^{\text {st }}-2^{\text {nd }}$ 2017, Surabaya - Indonesia

\begin{tabular}{|c|c|c|c|}
\hline No. & Related variable & Predictor variable & Multiple Linear Regression Equation \\
\hline 4. & $\begin{array}{c}\mathrm{A}_{3}: \text { Price of } \\
\text { equipment rental } \\
\text { wages }\end{array}$ & $\begin{array}{l}\mathrm{X}_{1}: \\
\text { Changes/additions } \\
\text { to the scope of work } \\
\mathrm{X}_{3}: \text { Unexpected } \\
\text { conditions } \\
\mathrm{X}_{4}: \text { Project } \\
\text { schedule delay } \\
\mathrm{X}_{5}: \text { Inflation rate } \\
\mathrm{X}_{7}: \text { Local area } \\
\text { reuirements } \\
\overline{\mathrm{X}_{1}}-\overline{\mathrm{X}_{7}}: \text { Average } \\
\text { value data } \\
\mathrm{SX}_{1}-\mathrm{SX}_{7}: \text { Standar } \\
\text { deviation data }\end{array}$ & $\begin{array}{l}\mathrm{A} 3=0.0420+0.00322\left(0.516\left(\frac{X 1-\overline{X 1}}{S X 1}\right)+0.243\left(\frac{X 3-\overline{X 3}}{S X 3}\right)+\right. \\
\left.0.458\left(\frac{X 4-\overline{X 4}}{S X 4}\right)+0.467\left(\frac{X 5-\overline{X 5}}{S X 5}\right)+0.496\left(\frac{X 7-\overline{X 7}}{S X 7}\right)\right)- \\
0.0148\left(0.144\left(\frac{X 1-\overline{X 1}}{S X 1}\right)-0.872\left(\frac{X 3-\overline{X 3}}{S X 3}\right)-0.249\left(\frac{X 4-\overline{X 4}}{S X 4}\right)+\right. \\
\left.0.152\left(\frac{X 5-\overline{X 5}}{S X 5}\right)+0.365\left(\frac{X 7-\overline{X 7}}{S X 7}\right)\right)\end{array}$ \\
\hline 5. & $\begin{array}{l}\mathrm{X}_{1} \text { : } \\
\text { Changes/additions } \\
\text { to the scope of work }\end{array}$ & $\begin{array}{l}\mathrm{B}_{1}: \text { Material } \\
\text { specification change } \\
\overline{\mathrm{B}_{1}}: \text { Average value } \\
\text { of data changes in } \\
\text { material } \\
\text { specification } \\
\mathrm{SB}_{1}: \text { Standard } \\
\text { deviation of data } \\
\text { changes in material } \\
\text { specification } \\
\mathrm{B}_{2}: \text { Acceleration of } \\
\text { work } \\
\overline{\mathrm{B}_{2}}: \text { The average } \\
\text { value of work } \\
\text { acceleration data } \\
\mathrm{SB}_{2}: \text { Standard } \\
\text { deviation of data } \\
\text { acceleration of work } \\
\mathrm{B}_{3}: \text { Design changes } \\
\overline{\mathrm{B}_{3}}: \text { Average value } \\
\text { of design change } \\
\text { data } \\
\mathrm{SB}_{3}: \text { Standard } \\
\text { deviation of design } \\
\text { changes data }\end{array}$ & $\begin{array}{l}\mathrm{X} 1= \\
0.0685+0.0084\left(0.691\left(\frac{B 1-\overline{B 1}}{S B 1}\right)+0.193\left(\frac{B 2-\overline{B 2}}{S B 2}\right)+0.696\left(\frac{B 3-\overline{B 3}}{S B 3}\right)\right)+ \\
0.0073\left(0.162\left(\frac{B 1-\overline{B 1}}{S B 1}\right)-0.981\left(\frac{B 2-\overline{B 2}}{S B 2}\right)+0.110\left(\frac{B 3-\overline{B 3}}{S B 3}\right)\right)\end{array}$ \\
\hline
\end{tabular}




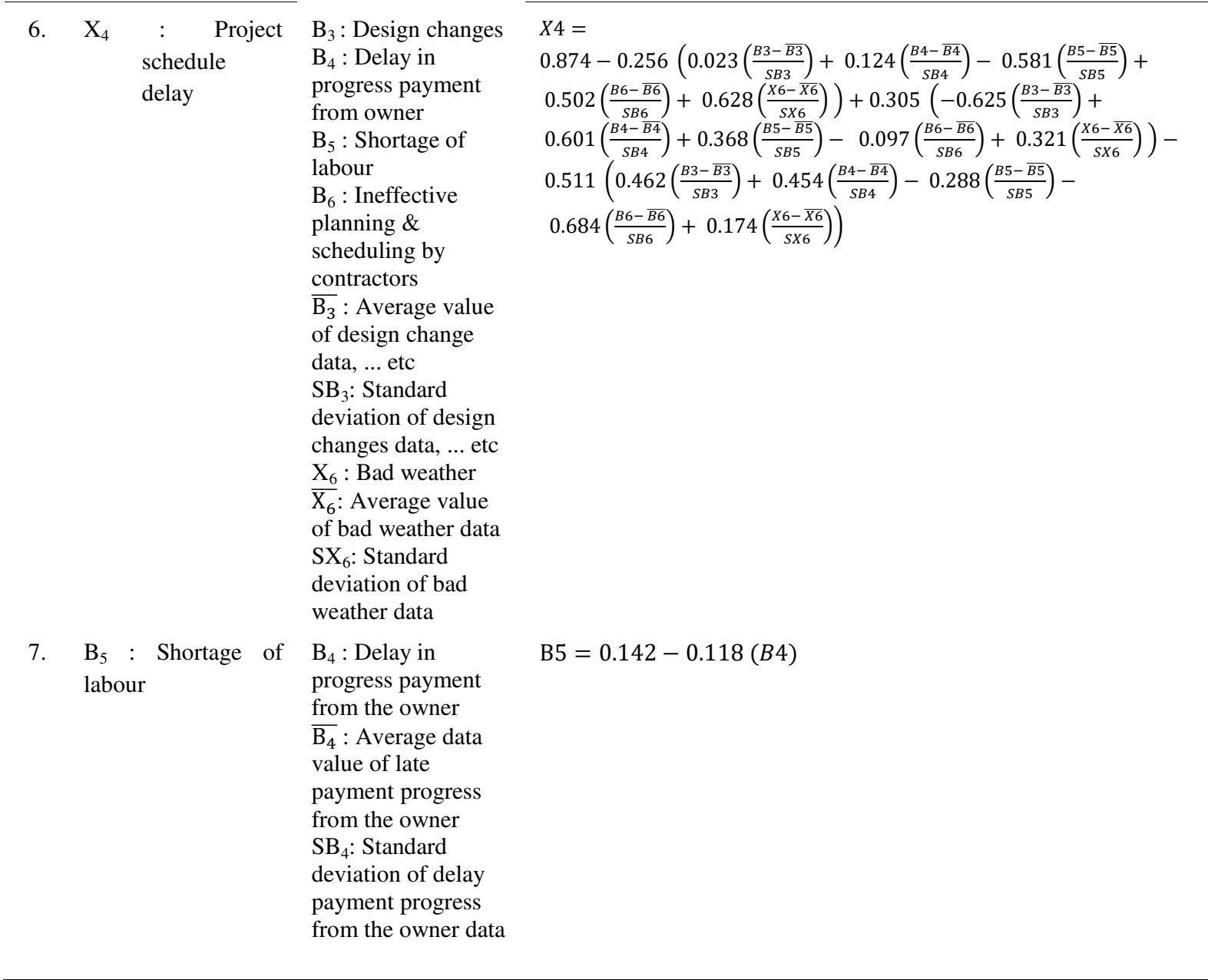

\section{B. Model Formulation and Graphic Analysis}

The multiple linear regression equation obtained still has limitations because it cannot see the behavior of each variable. Therefore we need further modeling using dynamic system. This study used Vensim Software to be simulated in order to see the relationship between factors that influence each other against the trend of cost escalation. This simulation is done with the aim to see the behavior of the system model that has been created, by entering the values on the constants and the function table in accordance with the condition in the real system. The simulation results are then used to understand the behavior, symptoms or processes and to know the trend/the tendency of cost escalation of multi-years project costs in the future. The modeling of factors that affect cost escalation can be seen in Figure 2 . 


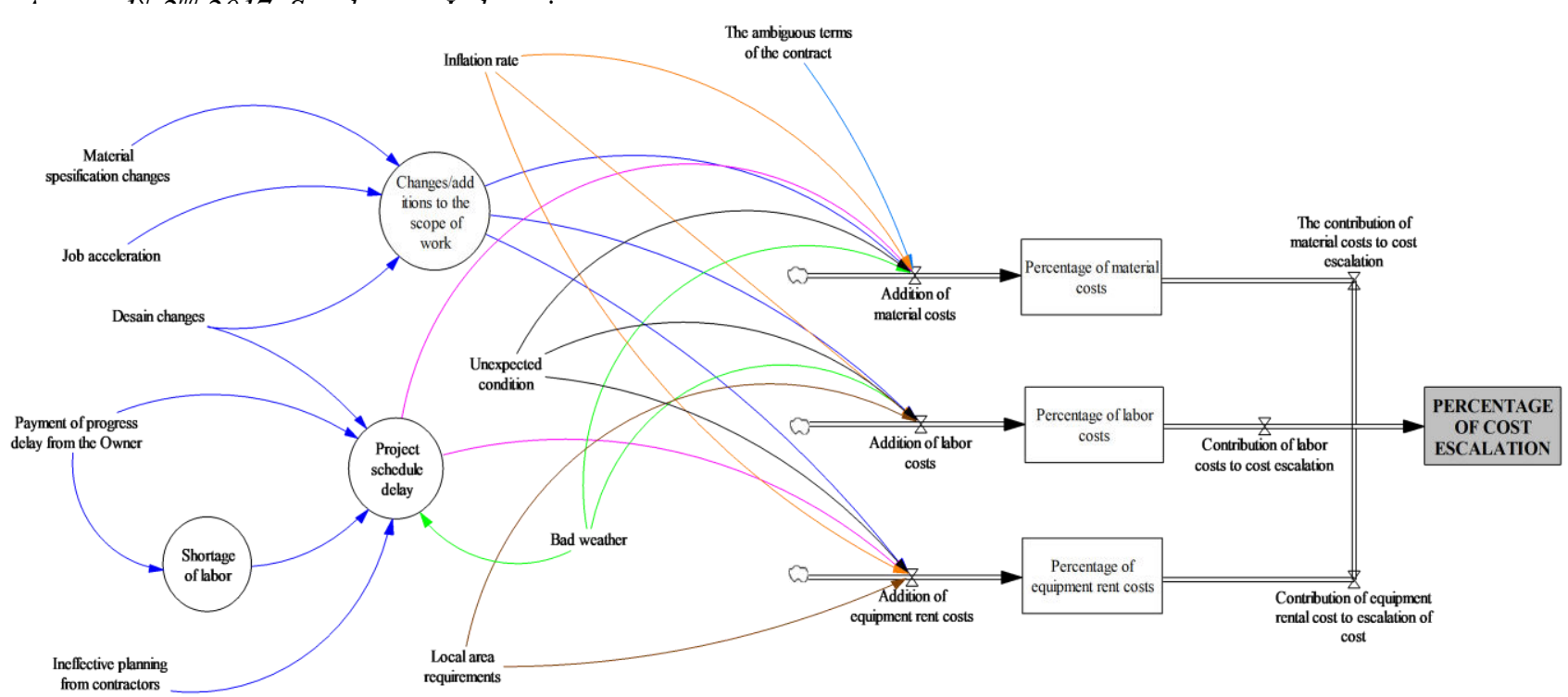

Figure 2. Stock Flow Diagram

This initial model is run with a span of twelve years that can be seen the amount of escalation costs in each year. However, in this study, the amount of escalation cost in the seventh year is chosen to approximate the real condition in the field, where the time of construction of multi years construction project of PT. PP in Surabaya generally runs five years and to predict the amount of escalation cost in the next two years. The results of running on this initial model can be seen in Figure 3 .

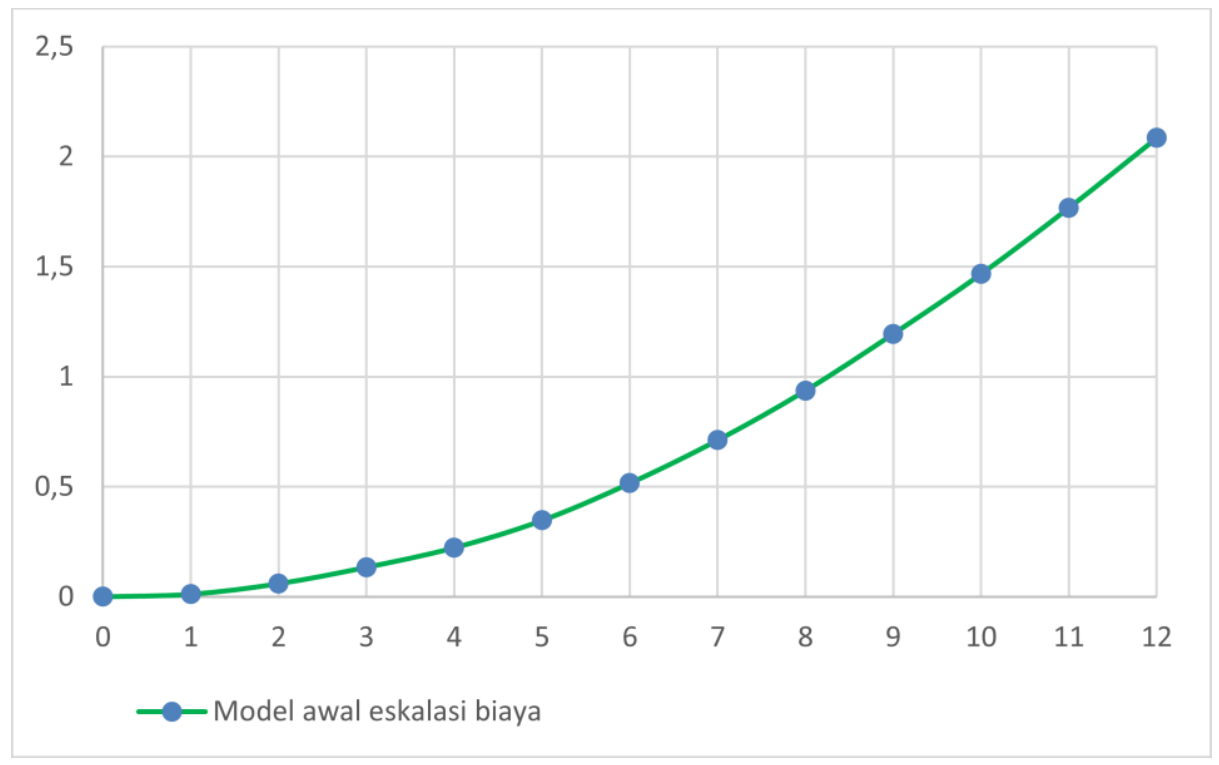

Figure 3. Graph Model of Early Model Running Results

The results of the initial model running in Figure 3 show the trend of multi-years projects cost escalation rates from the first year (zero), and second year, to the seventh year of escalation. The maximum result occurs in the seventh year, where the cost escalation incurred to $71.14 \%$ of the initial contract value of a project. 


\section{Model Validation}

Model validation was carried out by applying the model to data testing, by comparing the model simulation results with the data testing on the multi-years projects cost escalation level data that is not included in the data processing. The results obtained from the model validation test with the data testing showed that the proposed model can accurately predict the escalation of project costs with an accuracy of $91.21 \%$.

Comparative data is model simulation results with data testing, while data testing is taken from the multi-years cost escalation projects scale with a two year implementation duration (see Table 3). After comparing the two data, then calculated the difference between the data to be searched the percentage difference between model output with the data.

Percentage change $=((5.94 \%-5.46 \%)) /(5.46 \%)=8.79 \%$ Level of model prediction accuracy $=100 \%-8.79 \%=$ $91.21 \%$

\section{Model Scenario}

The scenarios that are conducted in this research are parameter scenario and structure scenario. In this study, the parameter scenario aims to see the most significant impact on the model output of the factors causing the cost escalation of multi-years projects. Existing parameters in the model such as changes in material specification, acceleration of work, design changes, late payment of progress from the owner, ineffective planning by contractors, ambiguous contract terms, inflation rate, unpredictable conditions, poor weather, and local requirements on the run/running one by one and seeing its impact on the model output.

The result of the parameter scenario showed that the unexpected condition parameter gave the most significant impact to the cost escalation scale of multiyears projects that is equal to $59,69 \%$ and followed by inflation rate parameter equal to $8,078 \%$ and bad weather equal to $6,613 \%$.

The second scenario is the structural scenario, where the initial model incorporates additional factors that can minimize the cost escalation of multi-years projects. These factors are derived from some literature that discuss about the attempts to reduce cost escalation. The factors included in the model are detailed project schedule, risk mitigation, initial contractor involvement in design development, and experts involvement in the project. These factors are incorporated and combined in such a way that the validated initial models in Vensim start from entering one by one of the existing factors, combining two factors, combining three factors, and the last four factors incorporated together to obtain optimal results in the effort of minimizing the escalation of multi-years project cost. The combination of scenarios performed in this study can be seen in Table 4.

Table 3. Validation Model

\begin{tabular}{ccc}
\hline Year & $\begin{array}{c}\text { Simulation } \\
\text { Model Result }\end{array}$ & $\begin{array}{c}\text { Data Testing Cost } \\
\text { Escalation of Project X }\end{array}$ \\
\hline 0 & 0 & - \\
1 & $1.17 \%$ & - \\
2 & $5.94 \%$ & $5.46 \%$ \\
3 & $13.40 \%$ & - \\
4 & $22.28 \%$ & - \\
5 & $34.68 \%$ & - \\
6 & $51.56 \%$ & - \\
7 & $71.14 \%$ & - \\
8 & $93.65 \%$ & - \\
9 & $119.45 \%$ & - \\
10 & $146.64 \%$ & - \\
11 & $176.69 \%$ & - \\
12 & $208.42 \%$ & - \\
\hline
\end{tabular}


The Third International Conference on Civil Engineering Research (ICCER)

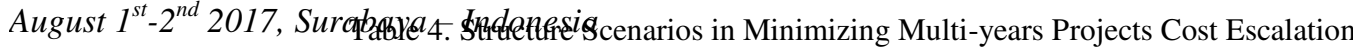

\begin{tabular}{|c|c|c|}
\hline Scenario & Additional Factors & Description \\
\hline Scenario 1 & Contractor initial involvement & Added \\
\hline Scenario 2 & Expert involvement & Added \\
\hline Scenario 3 & Project risk mitigation & Added \\
\hline Scenario 4 & Project schedule detailed & Added \\
\hline \multirow[t]{2}{*}{ Scenario 5} & Contractor inintial involvement & Added \\
\hline & Expert involvement & Added \\
\hline \multirow[t]{2}{*}{ Scenario 6} & Contractor inintial involvement & Added \\
\hline & Project risk mitigation & Added \\
\hline \multirow[t]{2}{*}{ Scenario 7} & Contractor inintial involvement & Added \\
\hline & Project schedule detailed & Added \\
\hline \multirow[t]{2}{*}{ Scenario 8} & Expert involvement & Added \\
\hline & Project risk mitigation & Added \\
\hline \multirow[t]{2}{*}{ Scenario 9} & Project risk mitigation & Added \\
\hline & Project schedule detailed & Added \\
\hline \multirow[t]{2}{*}{ Scenario 10} & Expert involvement & Added \\
\hline & Project schedule detailed & Added \\
\hline \multirow[t]{3}{*}{ Scenario 11} & Contractor inintial involvement & Added \\
\hline & Expert involvement & Added \\
\hline & Project risk mitigation & Added \\
\hline \multirow[t]{3}{*}{ Scenario 12} & Contractor inintial involvement & Added \\
\hline & Project risk mitigation & Added \\
\hline & Project schedule detailed & Added \\
\hline \multirow[t]{3}{*}{ Scenario 13} & Contractor inintial involvement & Added \\
\hline & Expert involvement & Added \\
\hline & Project schedule detailed & Added \\
\hline \multirow[t]{3}{*}{ Scenario 14} & Expert involvement & Added \\
\hline & Project risk mitigation & Added \\
\hline & Project schedule detailed & Added \\
\hline \multirow[t]{4}{*}{ Scenario 15} & Contractor inintial involvement & Added \\
\hline & Expert involvement & Added \\
\hline & Project risk mitigation & Added \\
\hline & Project schedule detailed & Added \\
\hline
\end{tabular}

From the results of structural development scenario analysis with the addition of several factors that can suppress the rate of escalation of multi-years project costs showed the positive results. The result of scenario simulation 1-15 showed the tendency of escalation rate of multi years project costs from second year until seventh year has decreased when compared to the result of base model graph. For example, scenario 15 gave the most significant decreased of multi-years cost escalation with $31.35 \%$ (see Table 5) or in other words, it can suppress the escalation rate of $55.94 \%$ in the seventh year of construction when compared to the result of initial model graph. This result is obtained by calculating the difference between the results of the seventh year in the initial model and the scenario 15 , then the percentage of the difference is searched.

Percentage change scenario $15=((71.14 \%-$
$31.35 \%)) /(71.14 \%)$




\section{CONCLUSION}

Based on the results of research that has been done by researchers to develop modeling cost escalation multiyears projects with dynamic system approach, here are some conclusions:

1. Factors that led to the escalation of multi-years project costs on the PT. PP (Persero) Tbk. project in Surabaya such as material specification change, job acceleration, design changes, payment of progress delay from the owner, ineffective planning, change/addition of scope of work, labor shortage, project schedule delay, ambiguous contract terms, inflation rate,

\section{V.}

[1] Assaf, S.A., and Al-Hejji, S. (2006), "Causes Of Delays in Large Construction Projects", International Journal of Project Management, Vol. 24, page 349357.

[2] Barlas, Y. (1996). Format Aspect of Model Validity and Validation in System Dynamics. System unexpected condition, bad weather, and local requirements. From all of these factors, the most dominant in affecting the multi-years project cost escalation scale is the unexpected condition factor (uncertainty of land condition) of $59.69 \%$.

2. Scenario results by including additional factors such as project schedule timing, risk mitigation, initial contractor involvement in design development, and expert involvement in the project into the model may provide $55.94 \%$ decrease in project cost escalation in the seventh year during the construction period.

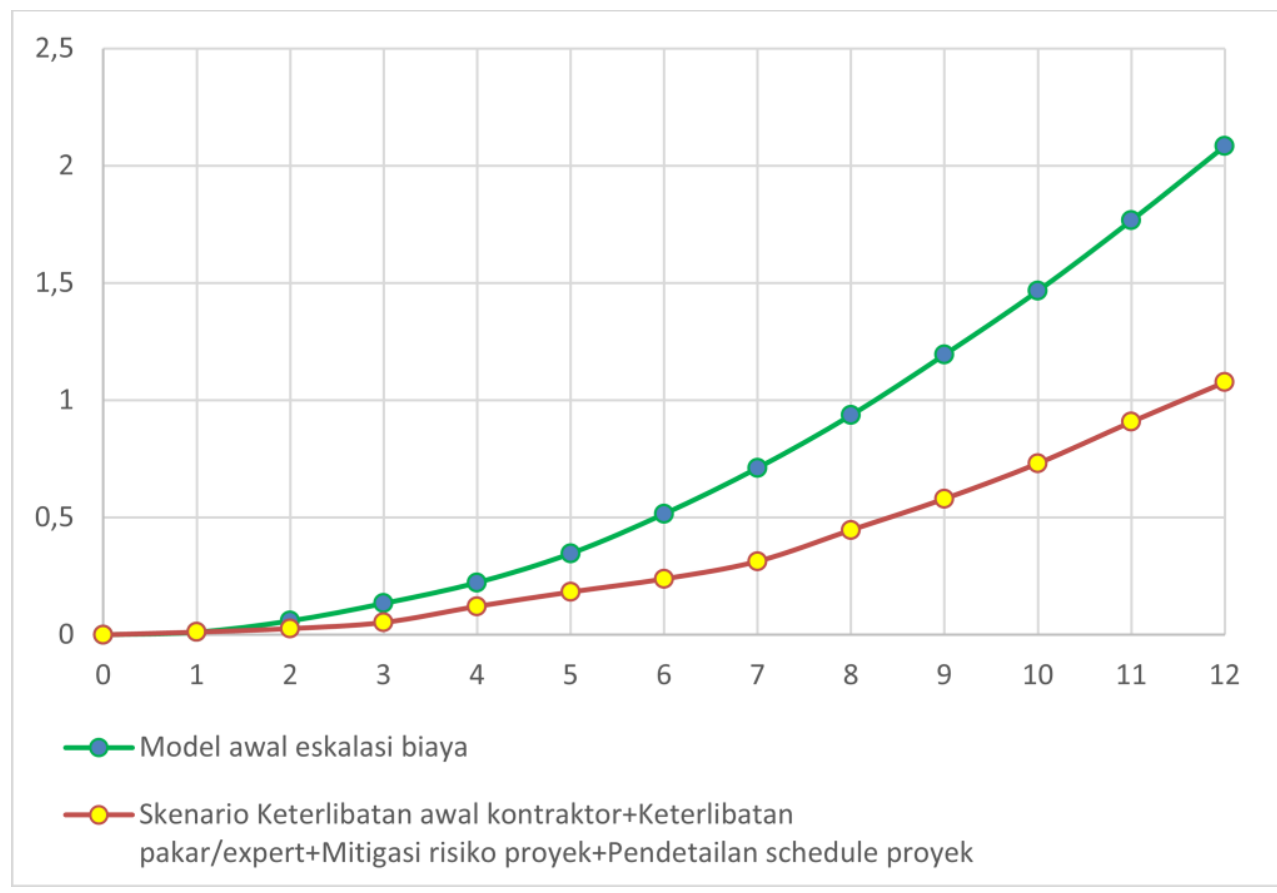

Figure 4. Graph Model Relation Scenario 15 (Contractor Initial Involvement, Expert Involvement / Expert, Project Risk Mitigation, and Detailed Project Schedule) on the Initial Model

Table 5. Simulation Results of Factor Addition of Contractor Initial Involvement, Expert Involvement, Project Risk Mitigation, and Detailed Project Schedule to Initial Model

\section{REFERENCES}

Dynamics Review. Pp. 12(3): 183-210.

[3] Bruni, M.E., Beraldi, P., Guerriero, F., and Pinto, E. (2011),"A Scheduling Methodology for Dealing with Uncertainty in Construction Projects", Engineering Computations: International Journal for ComputerAided Engineering and Software, Vol. 28, No. 8, 
, J.M.W. (2010), "Identifying The Critical Success Factors for Target Cost Contracts in The Construction Industry", Journal of Facilities Management, Vol. 8, No. 3, page 179-201.

[5] El-Razek, M.E.A, Bassioni, H.A., and Mobarak, A.M. (2008), "Causes of Delay in Building Construction Projects in Egypt", Journal Of Construction Engineering And Management, (ASCE) 0733-9364, 134:11(831).

[6] Forrester, Jay W. (1994), Sistem Dinamiks, System Thinking, and Soft OR. Sistem Dinamiks Review Summer, Vol. 10, No. 2, page 3.

[7] Kaliba, C., Muya, M., and Mumba K. (2009), "Cost escalation and schedule delays in road construction projects in Zambia”, International Journal of Project Management 27, page 522-531.

[8] Kareth, M., Tarore, H., Tjakra, J., and Walangitan, D. R. O. (2012), "Analisis Optimalisasi Waktu Dan Biaya Dengan Program Primavera 6.0 (Studi Kasus: Proyek Perumahan Puri Kelapa Gading)", Jurnal Sipil Statik, Vol 1, No. 1.

[9] Mentis, M. (2015), "Managing Project Risks and Uncertainties", Forest Ecosystems 2:2.

[10] Morris, Peter; Willson, William F. (2006), "Measuring and Managing Cost Escalation", AACE
International Transactions, Technology Collection pg. CS61.

[11] Nurmala, A., and Hardjomuljadi, S. (2015), "Penyebab dan Dampak Variation Order (VO) pada Pelaksanaan Proyek Konstruksi”, Junnal Konstruksia, Vol. 6, No. 2.

[12] Perez, P.B., Hitschfeld, M.L.C., Naranjo, M.A.G., and Cruz, M.C.G. (2015), "Climate and Construction Delays: Case Study in Chile", Engineering, Construction and Architectural Management, Vol 22, No. 6, page 596-621.

[13] Pourrostam, T., Ismail, A., and Mansournejad, M. (2011), "Identification and Evaluation of Causes and Effects of Change Orders in Building Construction Projects", Applied Mechanics and Materials, Vols 94-96, hal 2261-2264.

[14] Shane, J. S, et al. (2009), "Construction Project Cost Escalation Factors", Journal of Management in Engineering, Vol. 25, page 221-229.

[15] Touran, A., and Lopez, R. (2006), "Modeling Cost Escalation in Large Infrastructure Projects", Journal of Construction Engineering and Management, Vol. 132, No. 8, page 853-860. 